
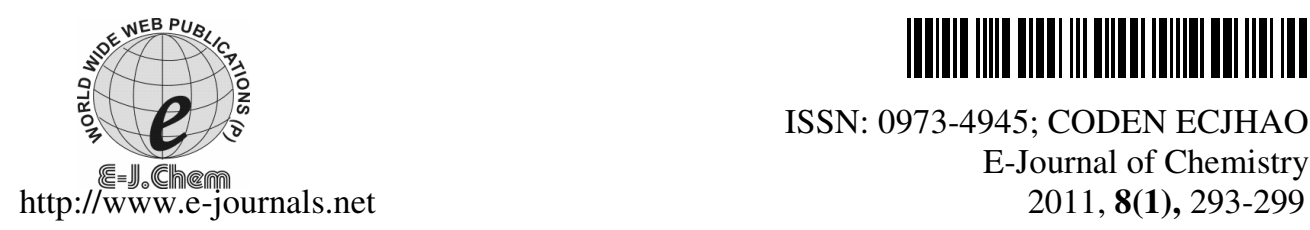

ISSN: 0973-4945; CODEN ECJHAO

E-Journal of Chemistry 2011, 8(1), 293-299

\title{
An Efficient Synthesis of Tetrahydrobenzo[b]pyran Derivatives Using Sulfonic Acid Functionalized Silica as an Efficient Catalyst
}

\author{
GHODSI MOHAMMADI ZIARANI ${ }^{\S *}$, ALIREZA ABBASI, \\ ALIREZA BADIEI and ZEINAB ASLANI ${ }^{\S}$ \\ ${ }^{\S}$ Department of Chemistry \\ Alzahra University, Vanak Square, Tehran, Iran \\ School of Chemistry, College of Science \\ University of Tehran, Tehran, Iran \\ gmziarani@gmail.com
}

Received 23 April 2010; Accepted 21 May 2010

\begin{abstract}
Tetrahydrobenzo[b]pyran derivatives were efficiently synthesized by the reaction of appropriated aromatic aldehydes, malononitrile and dimedone in the presence of $\mathrm{SiO}_{2}-\mathrm{Pr}-\mathrm{SO}_{3} \mathrm{H}$ as a nanoporous and recoverable solid acid catalyst, in good to excellent yields. Single crystal x-ray analysis conclusively confirmed the structure of the 2-amino-3-cyano-7,7-dimethyl-4(4-methylphenyl)-5-oxo-4H-5,6,7,8-tetrahydro-benzopyran.
\end{abstract}

Keywords: Tetrahydrobenzo[b]pyran, Dimedone, Aromatic aldehyde, Malononitrile, Sulfonic acid functionalized silica.

\section{Introduction}

Benzopyrans and their derivatives, in particular have shown several biological and pharmacological properties, such as spasmolytic, diuretic, antianaphylactin, antisterility and anticancer agents ${ }^{1}$. The polyfunctionalized benzopyrans were used as cosmetics, pigments and biodegradable agrochemicals ${ }^{2}$. Due to their applications, the syntheses of heterocyclic derivatives of these ring systems have great importance in medicinal chemistry and organic synthesis. Strategies for the synthesis of these compounds have varied from one-pot to multi-step approaches ${ }^{3}$. The simplest method involves one-pot, three-component condensation of malononitrile, an aldehyde and dimedone in different conditions. Various catalysts ${ }^{4}$ such as $\mathrm{Na}_{2} \mathrm{SeO}_{4}$, hexadecyldimethylbenzyl ammonium bromide ${ }^{5}, \mathrm{NaBr}^{6}$, tetramethyl ammonium hydroxide $\left(\mathrm{CH}_{3}\right)_{4} \mathrm{~N}^{+} \mathrm{OH}^{-7}{ }^{7} \mathrm{TEBA}^{8}{ }^{8} \mathrm{KF}$-montmorillonite ${ }^{9}$, KF-alumina ${ }^{10}$, organocatalysts $^{11}$, acetic acid ${ }^{12}$, diammonium hydrogen phosphate ${ }^{13}$ and hexadecyltrimethyl 
ammonium bromide ${ }^{14}$ have been used in this synthesis. Each method has own advantages and disadvantages, however, because of wide range of biological activities of Tetrahydrobenzo $[b]$ pyran derivatives, we would like to explore the catalytic activity of the silica based sulfonic acid $\left(\mathrm{SiO}_{2}-\mathrm{Pr}-\mathrm{SO}_{3} \mathrm{H}\right)$ as heterogenous nanoporous acid catalyst towards the synthesis of these products.

\section{Experimental}

IR spectra were recorded from $\mathrm{KBr}$ disk using a FT-IR Bruker Tensor 27 instrument. Melting points were measured by using the capillary tube method with an electro thermal 9200 apparatus. The ${ }^{1} \mathrm{H}$ NMR $(250 \mathrm{MHz})$ was run on a Bruker DPX, $250 \mathrm{MHz}$. x-ray crystallography were collected at ambient temperature by means of a STOE IPDS II, using graphite-monochromated Mo K $\alpha$ radiation $(\lambda=0.71073 \AA)$. Weight change curve in nitrogen were measured on a TA instrument TGA Q50 V6.3 with maximum heating rate of $20{ }^{\circ} \mathrm{C} / \mathrm{min}$. Nitrogen adsorption and desorption isotherms were measured at $-196{ }^{\circ} \mathrm{C}$ using a Japan Belsorb II system after the samples were vacuum dried at $150{ }^{\circ} \mathrm{C}$ overnight.

\section{Preparation of catalyst}

To $\mathrm{SiO}_{2}(20 \mathrm{~g})$ in dry toluene $(50 \mathrm{~mL})$, (3-mercaptopropyl)trimethoxysilane $(25 \mathrm{~mL})$ was added and the reaction mixture was refluxed for $24 \mathrm{~h}$. After this period, the mixture was filtered to obtain 3-mercaptopropylsilica which was washed with acetone and dried. 3-mercaptopropylsilica was oxidized with $\mathrm{H}_{2} \mathrm{O}_{2}$ (excess) in methanol $(20 \mathrm{~mL})$ for $24 \mathrm{~h}$ at room temperature and then the mixture was filtered and washed with $\mathrm{H}_{2} \mathrm{O}$ and acetone to obtain $\mathrm{SiO}_{2}-\mathrm{Pr}-\mathrm{SO}_{3} \mathrm{H}$ catalyst. The modified $\mathrm{SiO}_{2}-\mathrm{Pr}-\mathrm{SO}_{3} \mathrm{H}$ was dried and used as solid acid catalyst in the synthesis of tetrahydrobenzo[b]pyran derivatives.

\section{General procedure for the synthesis of tetrahydrobenzo[b]pyran derivatives}

A mixture of appropriated aromatic aldehydes $(1 \mathrm{mmol})$, malononitril $(1 \mathrm{mmol})$, dimedon $(1 \mathrm{mmol})$ and catalyst $\left(\mathrm{SiO}_{2}-\mathrm{Pr}-\mathrm{SO}_{3} \mathrm{H}\right)(0.03 \mathrm{~g})$, in water $(4 \mathrm{~mL})$ and ethanol $(1 \mathrm{~mL})$ were refluxed for appropriated time as mentioned in Table 2 . The progress of reaction was monitored by TLC. Upon completion of the reaction, the mixture was cooled to room temperature; the crude product was filtered off and washed with $\mathrm{H}_{2} \mathrm{O}$. Then the resulting solid was dissolved in hot ethanol, after filtration of catalyst and cooling of the filtrate, the pure crystals of tetrahydrobenzo[b]pyran derivatives will be obtained. The recovered catalyst can be washed consequently with diluted acid solution, water and then acetone. After drying, it can be reused without noticeable loss of reactivity. Spectral data for selected compounds:

\section{2-Amino-4-(4-Chlorophenyl)-3-cyano-7,7-dimethyl-5-oxo-4H-5,6,7,8-tetrahydro- benzopyran $(\mathbf{4 b})$}

IR (KBr): $v_{\max }=3390,3290,3180,2190,1660,1584 \mathrm{~cm}^{-1} .{ }^{1} \mathrm{H}$ NMR $\left(250 \mathrm{MHz}, \mathrm{DMSO}-\mathrm{d}_{6}\right)$ : $\delta=1.08\left(\mathrm{~s}, 3 \mathrm{H}, \mathrm{CH}_{3}\right), 1.12\left(\mathrm{~s}, 3 \mathrm{H}, \mathrm{CH}_{3}\right), 2.26\left(\mathrm{~s}, 2 \mathrm{H}, \mathrm{CH}_{2}-8\right), 2.46-2.48\left(\mathrm{~m}, 2 \mathrm{H}, \mathrm{CH}_{2}-6\right), 4.43$ (s,1H, CH-4), 6.58 (s, 2H, $\left.\mathrm{NH}_{2}\right), 7.18-7.28$ (m, 4H, ArH) (ppm).

\section{2-Amino-3-cyano-7,7-dimethyl-4-(3-nitrophenyl)-5-oxo-4H-5,6,7,8-tetrahydro- benzopyran (4c)}

IR $(\mathrm{KBr}): v_{\max }=3380,3323,3182,2188,1676,1634,1490,1405,1365,1216,1032,830$ $\mathrm{cm}^{-1} .{ }^{1} \mathrm{H}$ NMR $\left(250 \mathrm{MHz}, \mathrm{DMSO}-\mathrm{d}_{6}\right): \delta=0.89\left(\mathrm{~s}, 3 \mathrm{H}, \mathrm{CH}_{3}\right)-1.05\left(\mathrm{~s}, 3 \mathrm{H}, \mathrm{CH}_{3}\right), 2.06-2.28$ (d.d, $\left.2 \mathrm{H}, \mathrm{CH}_{2}-8\right), 2.50$ (2H, $\left.\mathrm{CH}_{2}-6\right), 4.20$ (s, $\left.1 \mathrm{H}, \mathrm{CH}-4\right), 7.07$ (s, 2H, $\mathrm{NH}_{2}$ ), $7.91-7.157$ (d, $2 \mathrm{H}, \mathrm{Ar}-\mathrm{H}), 7.36-7.33$ (d, 2H, Ar-H) ppm. 
2-Amino-3-cyano-7,7-dimethyl-4-(4-methylphenyl)-5-oxo-4H-5,6,7,8-tetrahydro benzopyran $(\mathbf{4 d})$

IR (KBr): $v_{\max }=3426,3329,2956,2191,1673,1639,1601,1510,1462,1439,1321,1248$, 1206, 1140, 1032, $976 \mathrm{~cm}^{-1} .{ }^{1} \mathrm{H}$ NMR $\left(250 \mathrm{MHz}, \mathrm{DMSO}-\mathrm{d}_{6}\right): \delta=1.02\left(\mathrm{~s}, 3 \mathrm{H}, \mathrm{CH}_{3}\right), 1.10(\mathrm{~s}$, $3 \mathrm{H}, \mathrm{CH}_{3}$ ), 2.16-2.20 (q, AB, 2H, $\left.\mathrm{CH}_{2}-8\right), 2.28$ (s, 3H, 3H), 2.47 (br, $\left.2 \mathrm{H}, \mathrm{CH}-6\right), 4.24$ (s, $1 \mathrm{H}$, CH-4), 6.16 (s, 2H, $\mathrm{NH}_{2}$ ), 7.06 (m, 4H, Ar-H) ppm.

2-Amino-3-cyano-7,7-dimethyl-4-(4-methoxyphenyl)-5-oxo-4H-5,6,7,8-tetrahydro benzopyran $(4 \mathrm{e})$

IR (KBr): $v_{\max }=3375,3318,2962,2193,1684,1655,1605,1508,1368,1252,975 \mathrm{~cm}^{-1} .{ }^{1} \mathrm{H}$ NMR $\left(250 \mathrm{MHz}, \mathrm{DMSO}-\mathrm{d}_{6}\right): \delta=0.94\left(\mathrm{~s}, 3 \mathrm{H}, \mathrm{CH}_{3}\right)-1.03\left(\mathrm{~s}, 3 \mathrm{H}, \mathrm{CH}_{3}\right), 2.05-2.27(\mathrm{dd}, 2 \mathrm{H}$, $\mathrm{CH}_{2}-8$ ), 2.49-2.50 (brs, 2H, CH-6), 3.71 (s, 3H, OCH ${ }_{3}$ ), 4.11 ( $\left.\mathrm{S}, 1 \mathrm{H}, \mathrm{CH}-4\right), 6.82-6085$ (d, 2H, Ar-H), 6.96 (s, 2H, NH N $_{2}, 7.06-7.032$ (d, 2H, Ar-H) ppm.

\section{Crystallography}

The data were collected at ambient temperature by means of a STOE IPDS II, using graphite-monochromated Mo K $\alpha$ radiation $(\lambda=0.71073 \AA)$. No intensity variations due to decomposition of the crystals were observed. Selected crystallographic and experimental details are summarized in Table 1. X-Area program packages were used for indexing and integrating the single crystal reflections ${ }^{15}$. Absorption corrections become important if the crystal is very anisotropic, i.e. a very thin plate. Due to a low absorption coefficient $\left(0.081 \mathrm{~mm}^{-1}\right)$, absorption correction is not required and the current case we neglect performing the correction ${ }^{16}$. The structure was solved by direct methods using SHELXS-97, and refined using full-matrix least-squares method on $F^{2}$, SHELXL-97 ${ }^{17}$. Molecular graphics were drawn by Diamond programs ${ }^{18}$ and PLATON ${ }^{19}$ software was used to prepare materials for publication. All non-hydrogen atoms were refined anisotropically. Aromatic, methane and amine $\mathrm{H}$ atoms were placed in calculated positions and constrained to ride on their parent atoms, with $U_{\text {iso }}(\mathrm{H})=1.2$ $U_{\text {eq }}(\mathrm{C} / \mathrm{N})$ and for methyl group $U_{\text {iso }}(\mathrm{H})=1.5 U_{\text {eq }}(\mathrm{C})$.

\section{Results and Discussion}

The synthesis of tetrahydrobenzopyran derivatives were achieved by the three-component condensation of an aromatic aldehyde $(1 \mathrm{mmol})$, malonitrile $(1 \mathrm{mmol})$ and dimedone $(1 \mathrm{mmol})$ in the presence of $0.02 \mathrm{~g}$ sulfonic acid functionalized silica in the mixture of ethanol and $\mathrm{H}_{2} \mathrm{O}$ (1:4) at reflux to give products in excellent yields (Scheme 1). For optimization of reaction conditions, 2-amino-3-cyano-7,7-dimethyl-4-(phenyl)-5-oxo-4H-5,6,7,8-tetrahydro-benzopyran (4a) was synthesized in different solvents. As shown in Table 1, the mixture of water and ethanol (4:1) was the most effective solvent for this reaction. The key advantages of this condition are the very short reaction time and high yield of products.<smiles>CC1(C)CC(=O)CC(=O)C1</smiles>

1<smiles>[X]c1ccc(C=O)cc1</smiles>

2

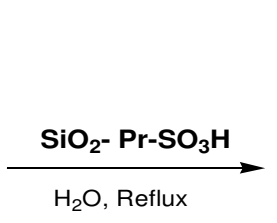

3

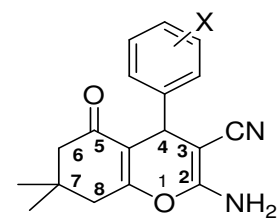

4

Scheme 1 
Table 1. Solvent optimization in the synthesis 2-Amino-3-cyano-7,7-dimethyl-4-(phenyl)-5oxo-4H-5,6,7,8-tetrahydro-benzopyran (4a)

\begin{tabular}{cccc}
\hline Entry & Solvent & Time & Yield, \% \\
\hline 1 & $\mathrm{H}_{2} \mathrm{O}$ & $5 \mathrm{~h}$ & 97 \\
2 & $\mathrm{EtOH}$ & $180 \mathrm{~min}$ & 78 \\
3 & $\mathrm{EtOH} / \mathrm{H}_{2} \mathrm{O}(1: 1)$ & $120 \mathrm{~min}$ & 97 \\
4 & $\mathrm{EtOH} / \mathrm{H}_{2} \mathrm{O}(1: 4)$ & $15 \mathrm{~min}$ & 97 \\
\hline
\end{tabular}

Yields are related to isolated pure products

In the current study, tetrahydrobenzo[b]pyran derivatives were prepared according to the one-pot three-component Tandem Knoevenagel-cyclocondensation reaction. As it is shown in Scheme 2, the solid acid catalyst, firstly protonates the aldehyde carbonyl group, which then condenses with malononitirle via the Knoevenagel type coupling to produce the $\alpha$-cyanocinnamonitrile derivatives (5). Michael addition reaction of $\mathbf{5}$ with dimedone followed by rearrangement and cyclization give rise to 2-amino-4-aryl-3-cyano-7,7dimethyl-5-oxo-4H-5,6,7,8-tetrahydrobenzopyran (4) in good to excellent yield.
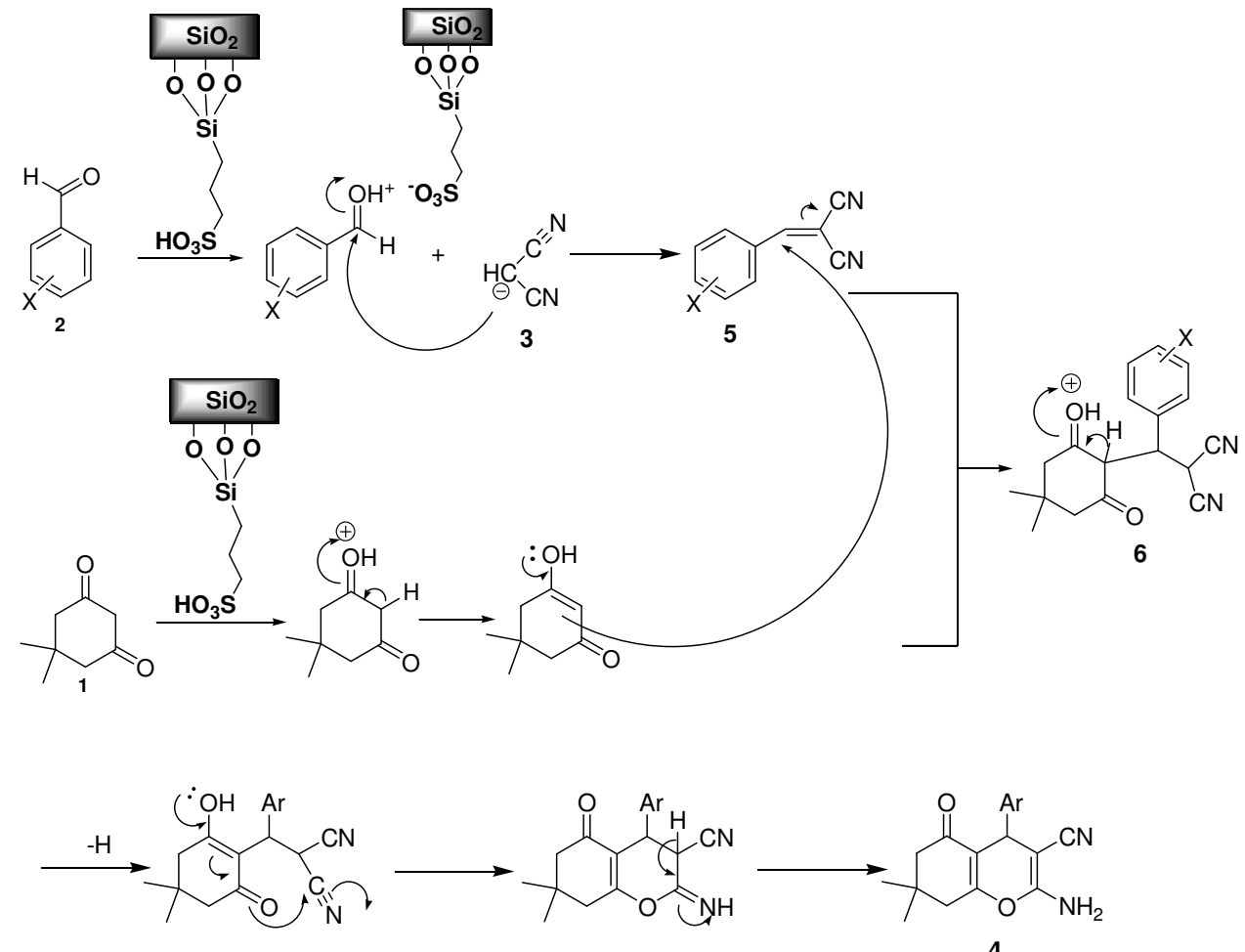

\section{Scheme 2}

The results were shown in Table 2. The high yields of reaction are attributed to the effect of nano pore size about $5.9 \mathrm{~nm}$ of solid acid catalyst, which could act as nanoreactor. The products were characterized by comparison of their melting points, ${ }^{1} \mathrm{H}$ NMR and IR spectra with the corresponding values from the literatures. Single-crystal $\mathrm{X}$-ray analysis of $\mathbf{4 d}$ was conclusively confirmed by the structure of the isolated products. An ORTEP diagram of $\mathbf{4 d}$ is shown in Figure 1. 


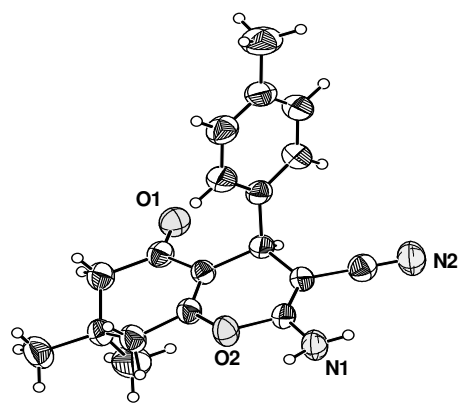

Figure 1. ORTEP structure of the compound $\mathbf{4 d}$, showing $50 \%$ probability ellipsoids $\mathrm{H}$ atoms are shown as circles of arbitrary radii

The results in Table 2 show that, $\mathrm{SiO}_{2}-\mathrm{Pr}-\mathrm{SO}_{3} \mathrm{H}$ is an efficient heterogeneous nanoporous solid acid in this reaction because of high yield of reaction. Karimi ${ }^{20}$ and $\mathrm{Paul}^{21}$ have used the $\mathrm{SiO}_{2}-\mathrm{Pr}-\mathrm{SO}_{3} \mathrm{H}$ catalyst to carry out variety of reactions. It has been used in organic synthesis by our group ${ }^{22}$.

Table 2. $\mathrm{SiO}_{2}-\mathrm{Pr}-\mathrm{SO}_{3} \mathrm{H}$ catalyzed the synthesis of tetrahydrobenzo[b]pyran derivatives

\begin{tabular}{ccccccc}
\hline \multirow{2}{*}{ Entry } & \multirow{2}{*}{ Aldehyde } & Product & $\begin{array}{c}\text { Time, } \\
\text { min }\end{array}$ & $\begin{array}{c}\text { Yield } \\
\%\end{array}$ & m.p. & m.p. (Lit) \\
\hline 1 & $\mathrm{Ph}$ & $\mathbf{4 a}$ & 15 & 97 & $230-232$ & $228-230^{7}$ \\
2 & $4-\mathrm{ClC}_{6} \mathrm{H}_{4}$ & $\mathbf{4 b}$ & 20 & 90 & $237-239$ & $239-241^{5 \mathrm{a}}$ \\
3 & $3-\mathrm{NO}_{2} \mathrm{C}_{6} \mathrm{H}_{4}$ & $\mathbf{4 c}$ & 15 & 90 & $210-212$ & $213-214^{5 \mathrm{a}}$ \\
4 & $4-\mathrm{CH}_{3} \mathrm{C}_{6} \mathrm{H}_{4}$ & $\mathbf{4 d}$ & 25 & 98 & $214-216$ & $220-222^{5 \mathrm{a}}$ \\
5 & $4-\mathrm{OCH}_{3} \mathrm{C}_{6} \mathrm{H}_{4}$ & $\mathbf{4 e}$ & 25 & 98 & $190-192$ & $196-198^{5 \mathrm{a}}$ \\
6 & $2,4-\mathrm{Cl}_{2} \mathrm{C}_{6} \mathrm{H}_{4}$ & $\mathbf{4 f}$ & 20 & 92 & $118-119$ & $116-118^{14 b, c}$ \\
7 & $4-\mathrm{NO}_{2} \mathrm{C}_{6} \mathrm{H}_{4}$ & $\mathbf{4 g}$ & 15 & 93 & $176-178$ & $176-178^{5 \mathrm{a}}$ \\
8 & $3,4-\left(\mathrm{OCH}_{3}\right)_{2} \mathrm{C}_{6} \mathrm{H}_{4}$ & $\mathbf{4 h}$ & 35 & 85 & $170-172$ & $170-173^{5 \mathrm{~b}}$ \\
9 & $4-\mathrm{OHC}_{6} \mathrm{H}_{4}$ & $\mathbf{4 i}$ & 30 & 90 & $205-207$ & $206-208^{7}$ \\
\hline
\end{tabular}

For preparation of the catalyst, at first, the surface of silica was grafted by (3-mercaptopropyl)trimethoxysilane and then the thiol functionalities were oxidized by hydrogen peroxide into sulfonic acid groups (Scheme 3$)^{23-24}$. The TGA of catalyst (Figure 2) shows two decomposition states: one below $100{ }^{\circ} \mathrm{C}$ ( $4 \%$ weight loss), assigned to loss of water surface and one more mass loss between $100{ }^{\circ} \mathrm{C}$ and $550{ }^{\circ} \mathrm{C}(16 \%$ weight loss $)$, corresponded to the decomposition of organic groups $\left(\mathrm{PrSO}_{3} \mathrm{H}\right)$ anchored onto silica and the water loss during the condensation of silanol to siloxane groups. The surface area, pore volume and average pore diameter of $\mathrm{SiO}_{2}-\mathrm{Pr}-\mathrm{SO}_{3} \mathrm{H}$ are $440 \mathrm{~m}^{2} \mathrm{~g}^{-1}, 0.43 \mathrm{~cm}^{3} \mathrm{~g}^{-1}$ and $5.9 \mathrm{~nm}$, respectively, which are smaller than $\mathrm{SiO}_{2}$ due to the immobilization of organic groups (propyl sulfonic acid) into the pores (Table 3$)^{22}$.

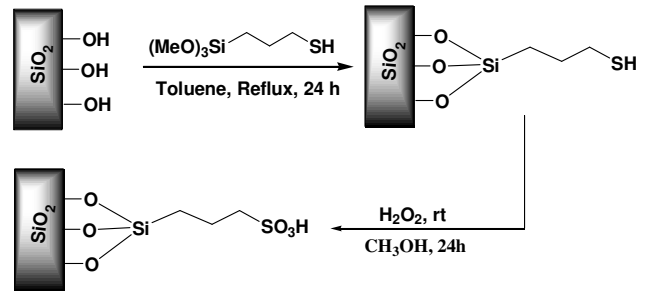

Scheme 3 


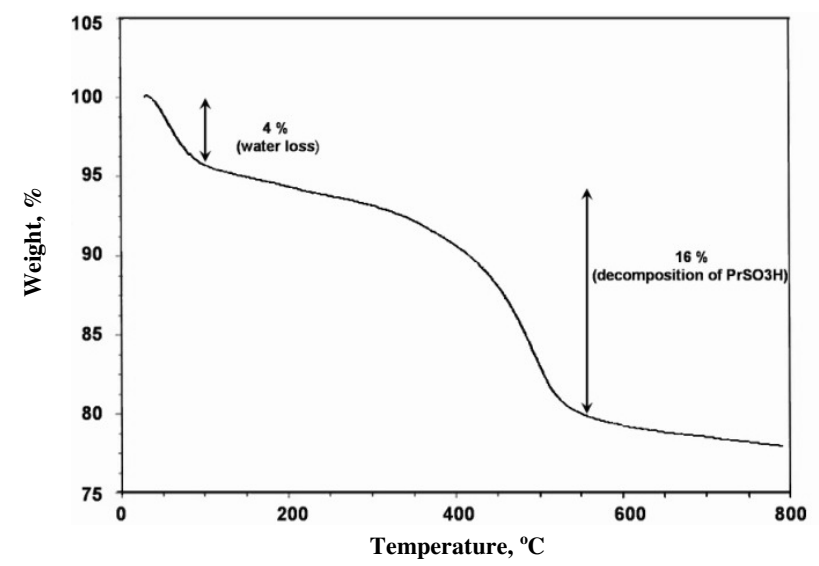

Figure 2. Thermal gravimetric analysis of the $\mathrm{SiO}_{2}-\mathrm{Pr}-\mathrm{SO}_{3} \mathrm{H}$ in $\mathrm{N}_{2}$ flow

Table 3. Surface area, pore size and pore volume of silica gel and $\mathrm{SiO}_{2}-\mathrm{Pr}-\mathrm{SO}_{3} \mathrm{H}$

\begin{tabular}{cccc}
\hline Name & $\begin{array}{c}\text { Surface area, } \\
\mathrm{m}^{2} / \mathrm{g}\end{array}$ & $\begin{array}{c}\text { Total pore volume, } \\
\mathrm{cm}^{3} / \mathrm{g}\end{array}$ & $\begin{array}{c}\text { Average pore } \\
\text { diameter, } \mathrm{nm}\end{array}$ \\
\hline $\mathrm{SiO}_{2}$ & 499 & 0.737 & 6.4 \\
$\mathrm{SiO}_{2}-\mathrm{Pr}_{-} \mathrm{SO}_{3} \mathrm{H}$ & 440 & 0.430 & 5.9 \\
\hline
\end{tabular}

The efficiency of various catalysts in synthesis of 2-amino- $4 H$-Benzopyran derivatives has been compared in Table 4 . The best yield and short reaction time is attributed to the high efficiency of the nano-catalyst of $\mathrm{SiO}_{2}-\mathrm{Pr}-\mathrm{SO}_{3} \mathrm{H}$.

Table 4. Comparison of efficiency of various catalysts in synthesis of 2-amino- $4 \mathrm{H}$ Benzopyran derivatives

\begin{tabular}{cccccc}
\hline Entry & Catalyst & Solvent & Time & Yield, \% & Ref. \\
\hline 1 & $\mathrm{NaBr}$ & free & $10-15 \mathrm{~min}$ & $60-95$ & {$[6]$} \\
2 & $(\mathrm{~S})-\mathrm{Proline}$ & $\mathrm{H}_{2} \mathrm{O} / \mathrm{EtOH}$ & $30 \mathrm{~min}$ & $78-98$ & {$[13 \mathrm{~b}]$} \\
3 & $\mathrm{HDMBAB}^{*}$ & $\mathrm{H}_{2} \mathrm{O}$ & $7-8 \mathrm{~h}$ & $84-93$ & {$[5 \mathrm{a}]$} \\
4 & $\mathrm{Na}_{2} \mathrm{SeO}_{4}$ & $\mathrm{EtOH} / \mathrm{H}_{2} \mathrm{O}$ & $0.75-3 \mathrm{~h}$ & $80-98$ & {$[4]$} \\
5 & $\mathrm{TMAH}^{* * *}$ & $\mathrm{H}_{2} \mathrm{O}$ & $0.5-2 \mathrm{~h}$ & $79-93$ & {$[7]$} \\
6 & $\mathrm{TBAF}^{* * *}$ & $\mathrm{H}_{2} \mathrm{O}$ & $30-300 \mathrm{~min}$ & $73-98$ & {$[14 \mathrm{~d}]$} \\
7 & $\mathrm{MgO}_{8}$ & $\mathrm{EtOH} / \mathrm{H}_{2} \mathrm{O}$ & $22-33 \mathrm{~min}$ & $90-96$ & {$[14 \mathrm{c}]$} \\
8 & $\mathrm{SiO}_{2}-\mathrm{Pr}-\mathrm{SO}_{3} \mathrm{H}$ & $\mathrm{H}_{2} \mathrm{O}$ & $8-20 \mathrm{~min}$ & $88-97$ & This work \\
\hline \multirow{2}{*}{ Hexadecyldimethylbenzyl ammonium bromide, } & ${ }^{* *}$ Tetra-methyl ammonium hydroxide, ${ }^{* * *}$ Tetrabutyl \\
Tmonium fluorid
\end{tabular}

\section{Conclusion}

In conclusion we have demonstrated a novel one-pot, three-component synthesis of 2-amino-4aryl-3-cyano-7,7-dimethyl-5-oxo-4H-5,6,7,8-tetrahydrobenzopyran derivatives using sulfonic acid functionalized silica $\left(\mathrm{SiO}_{2}-\mathrm{Pr}-\mathrm{SO}_{3} \mathrm{H}\right)$ as an efficient heterogeneous solid acid catalyst in good to excellent yield. The simplicity of reaction, recovery of catalyst without loss of reactivity, high yield products and short time of reaction offer improvements over many existing methods.

\section{Acknowledgment}

We gratefully acknowledge for financial support from the Research Council of Alzahra University and University of Tehran. 


\section{References}

1. (a) Morianka Y and Takahashi K J, Japan Kokai, 1977, 17, 498-507; (b) Montandon J B, Zijlstra F J and Wilson J H P, Int J Tissue React., 1989, 11, 107-109; (c) Brooks G T, J Pestic Sci., 1998, 22, 41-50; (d) Hyana T and Saimoto H, J Patent, 1987, 621812768.

2. (a) Hafez E A A, Elnagdi M H, Elagamey A G A and EL-Taweel F M A A, Heterocycles, 1987, 26, 903; (b) Abdel Galil F M, Riad B Y, Sherif, S M and Elnagdi M H, Chem Lett., 1982, 1123.

3. EI-Agrody A M, J Chem Res (S), 1994, 280.

4. Hekmatshoar R, Majedi S and Bakhtiari K, Catal Commun., 2008, 9, 307.

5. (a) Jin T S, Wang A Q, Shi F, Han L S, Liu, L B and Li T S, ARKIVOC, 2006, (xiv), 78-86; (b) Wang X S, Shi D Q, Tu S J and Yao C S, Synth Commun., 2003, 33, 119.

6. $\quad$ Devi I and Bhuyan P J, Tetrahedron Lett., 2004, 45, 8625-8627.

7. Balalaie S, Sheikh-Ahmadi M and Bararjanian M, Catal Commun., 2007, 8, 1724-1728.

8. Rong L, Li X, Wang H, Shi D, Tu S and Zhuang Q, Synth Commun., 2006, 36, 2363.

9. Zhuang Q Y, Wu N, Shi D Q, Tu S J and Wang X S, Chin J Org Chem., 2006, 26, 1217.

10. Wang X S, Shi D Q, Tu S J and Yao C S, Synth Commun., 2003, 33, 119-126.

11. Lian X Z, Huang Y, Li Y Q and Zheng W J, Monatshefte fur Chemie, 2008, 139, 129.

12. Kamaljit S, Jasbir S and Harjit S, Tetrahedron, 1996, 52, 14273.

13. a) Balalaie S, Bararjanian M, Sheikh-Ahmadi M, Hekmat S and Salehi P, Synth Commun., 2007, 37, 1097; (b) Balalaie S, Bararjanian M, Amani A M and Movassagh B, Synlett., 2006, 263-266.

14. (a) Jin T S, Wang A Q, Wang X, Zhang J S and Li T S, Synlett., 2004, 871; (b) Wang L M, Shao J H, Tian H, Wang Y H and Liu B, J Fluorine Chem., 2006, 127, 97; (c) Seifi M and Sheibani H, Catal Lett., 2008, 126, 275; (d) Gao S, Tsai C H, Tseng C and Yao C F, Tetrahedron, 2008, 64, 9143.

15. Stoe \& Cie, X-AREA, vesion 1.43: Program for the Acquisition and Analysis of Data; Stoe \& Cie GmbH: Darmatadt, Germany, 2007.

16. Massa W, Crystal Structure Determination, Springer, Berlin, 2004.

17. Sheldrick G M, SHELXS97 and SHELXL97. University of Göttingen, Germany, 1997.

18. Brandenburg K, DIAMOND. Crystal Impact GbR, Bonn, Germany, 2001.

19. Spek A L, J Appl Cryst., 2003, 36, 7-13.

20. Karimi B and Khalkhali M, J Mol Catal A: Chem., 2005, 232, 113-117.

21. Gupta R, Paul S and Gupta R, J Mol Catal A: Chem., 2007, 266, 50-54.

22. Mohammadi Ziarani G, Badiei A, Abbasi A and Farahani Z, Chin J Chem., 2009, 27, 1537-1542.

23. Lim M H, Blandford C F and Stein A, Chem Mater, 1998, 10, 467-470.

24. Van Rhijn W M, De Vos D E, Sels B F and Bossaert W D, Chem Commun., 1998, 317-318. 


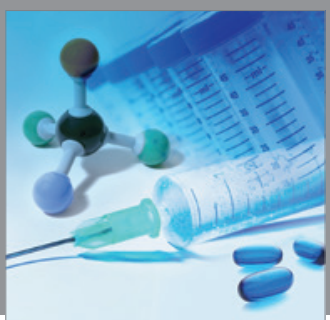

International Journal of

Medicinal Chemistry

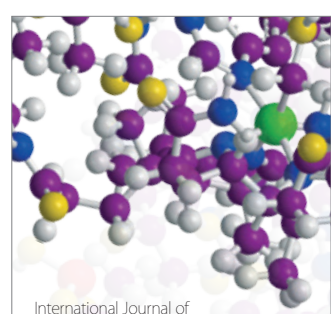

Carbohydrate Chemistry

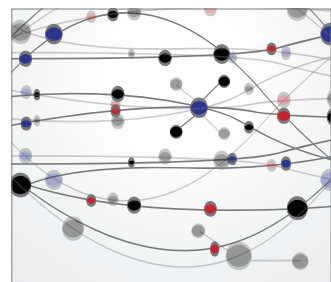

The Scientific World Journal
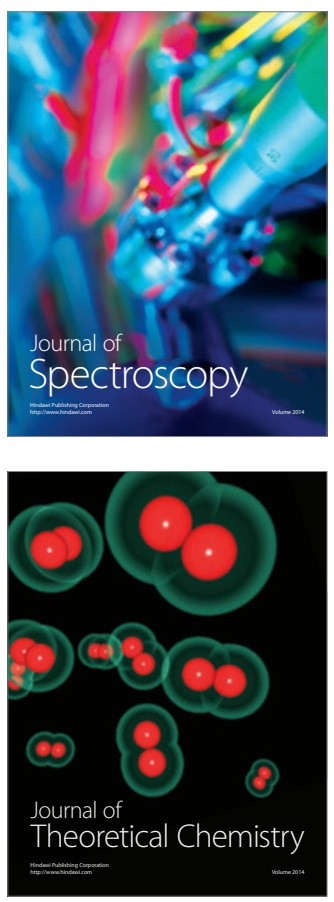
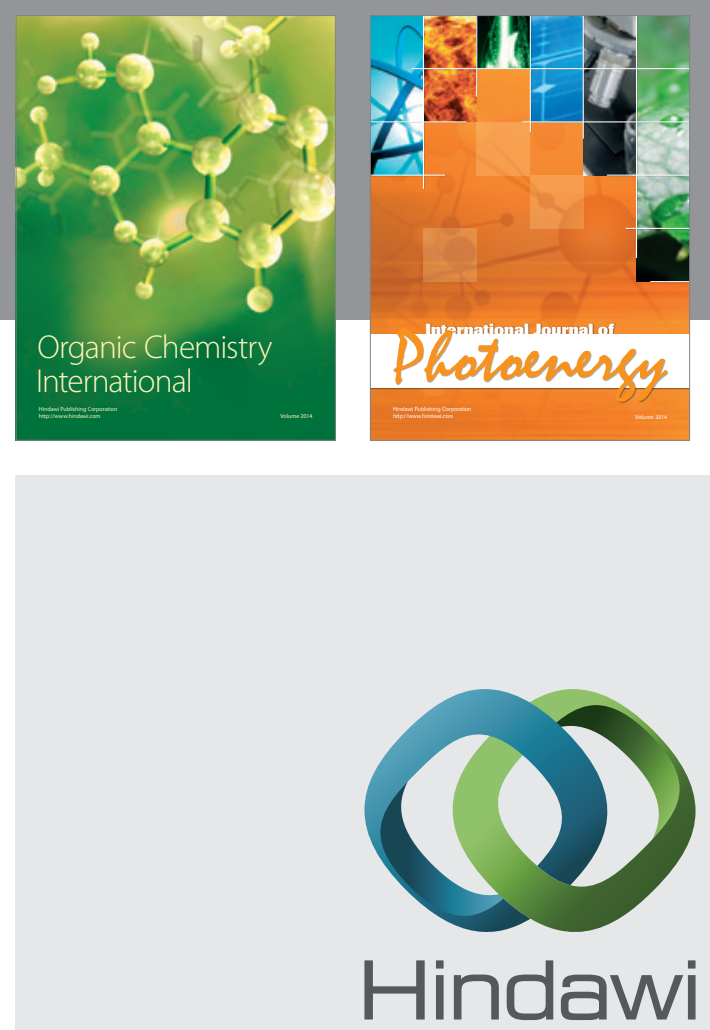

Submit your manuscripts at

http://www.hindawi.com
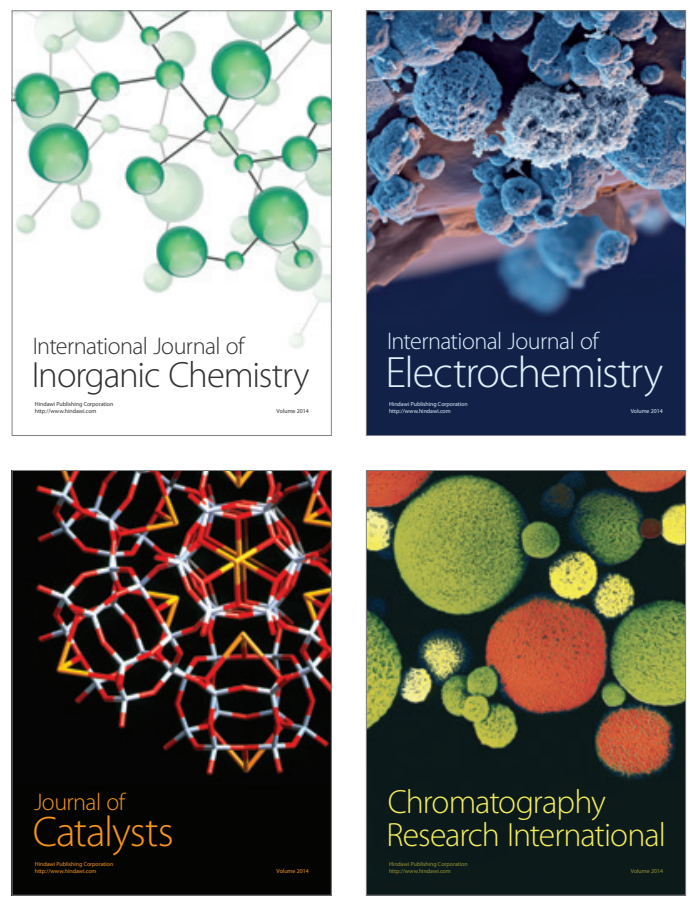
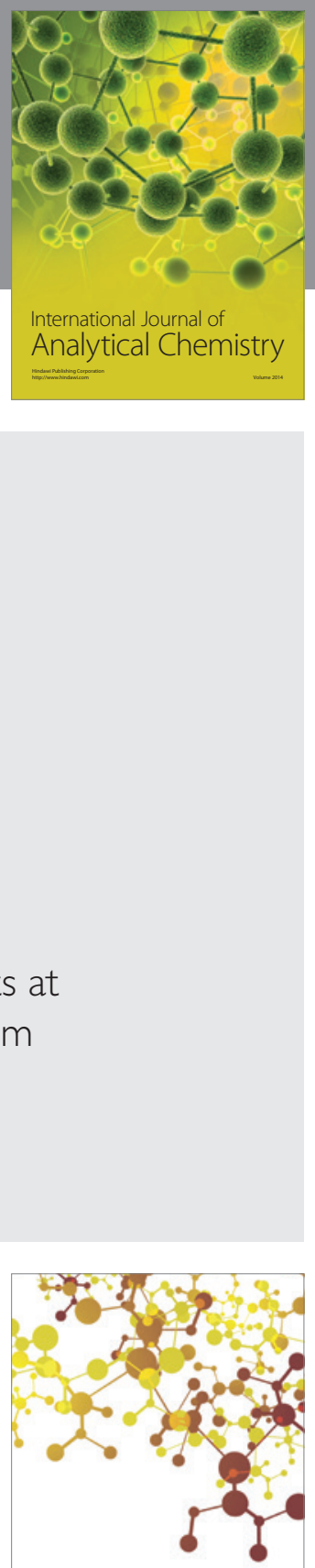

Journal of

Applied Chemistry
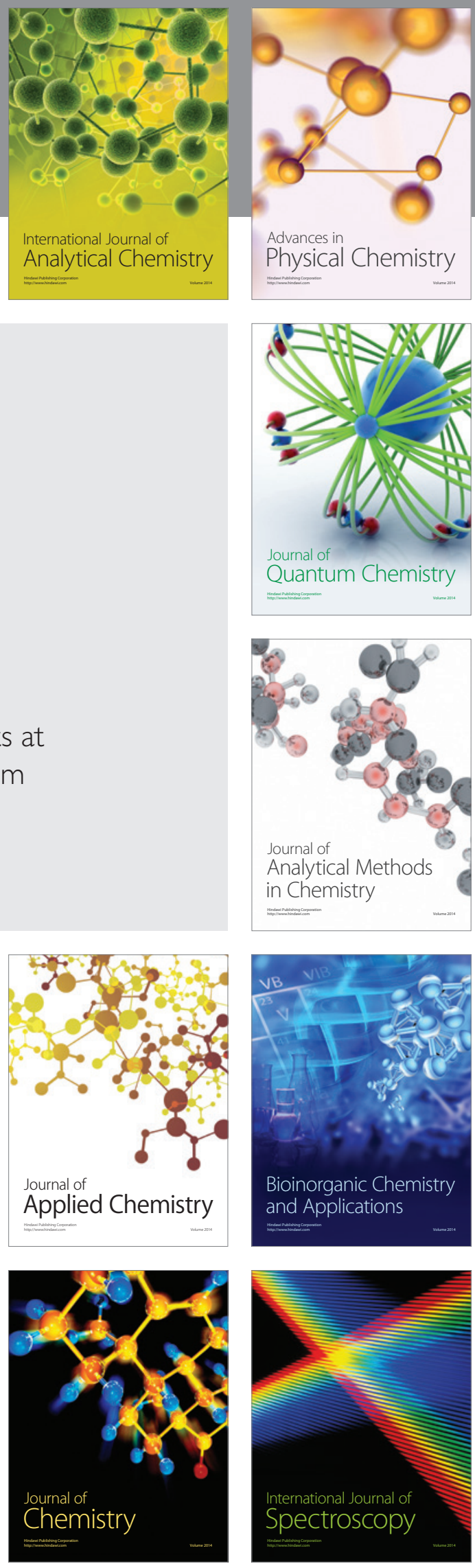